Proc. Estonian Acad. Sci. Biol. Ecol., 2003, 52, 4, 365-377

\title{
Changes in the benthic community structure and assessment of the water quality and the state of the ecosystems of Neva Bay and the eastern Gulf of Finland in 1994-2001
}

\author{
Evgeniya V. Balushkina* and Nonna P. Finogenova
}

Zoological Institute, Russian Academy of Sciences, Universitetskaya nab. 1, St. Petersburg, 199034, Russia

Received 20 December 2002, in revised form 29 May 2003

\begin{abstract}
Zoobenthic communities of Neva Bay and the eastern Gulf of Finland were determined using a complex of structure indices, such as species composition, number of species, abundance, biomass, and indices calculated on their basis, in particular the Shannon diversity index. The state of the ecosystems and the quality of the water of Neva Bay and the eastern Gulf of Finland were assessed using the Integrated Index (IP) specially devised for these ecosystems. It was shown that in 1994 through 2001 the role of oligochaetes in Neva Bay increased gradually, whereas the role of other taxa of benthic invertebrates declined. The water quality in the major part of Neva Bay was assessed by IP for 2001 as "polluted-dirty" and the state of the ecosystem as "crisis". In the northern shallow area of the eastern Gulf of Finland eurybiont species of the freshwater complex, i.e. oligochaetes, chironomid larvae, and molluscs of the Pisidiidae family, dominated in terms of biomass over other groups of aquatic organisms during the study period. The assessment of the state of the eastern Gulf of Finland in 2001 showed that with an increase of depth and salinity in the western direction the degree of pollution declined.
\end{abstract}

Key words: zoobenthos, pollution, water quality assessment, ecosystem.

\section{INTRODUCTION}

In spite of the deterioration of the ecological state of water bodies there is no generally accepted system for the evaluation of water quality. The two major directions among the numerous approaches may be conventionally termed a "water management approach" and an "ecological approach". The "ecological

\footnotetext{
* Corresponding author, balushkina@zin.ru
} 
approach" envisages restriction of the anthropogenic impacts on the biosphere, with rearrangements of the structure and metabolism of separate components of the biota (ecological modifications) regarded as the most reliable criteria of the ecological standards (Izrael \& Abakumov, 1991).

The methods based on structural characteristics of zoobenthos have been traditionally most widely used for the assessment of water quality and the state of marine and freshwater ecosystems (Leppäkoski, 1975; Balushkina, 1987; Johnson et al., 1992). In the monitoring of Finnish coastal waters macrozoobenthos is used as a measure of the state of ecosystems (Kauppila \& Bäck, 2001).

The structural and functional characteristics of benthic communities were used for the assessment of the water quality and the state of Neva Bay and the eastern Gulf of Finland in the early 1980s (Alimov \& Golubkov, 1987; Finogenova et al., 1987). Nowadays, the Neva estuary is one of the most eutrophicated and degraded areas of the Baltic Sea influenced by waste discharges from St. Petersburg (Telesh et al. 1999; Balushkina, 2002; Golubkov et al., 2003).

The aims of the present work are: (1) to characterize in detail the anthropogenic change of the structure of benthic communities of Neva Bay and the eastern part of the Gulf of Finland; (2) to distinguish the major features of "ecological modifications" of benthic communities characteristic of zones of different degrees of pollution; (3) to assess the state and water quality of ecosystems of Neva Bay and the eastern part of the Gulf of Finland in 1994-2001.

\section{STUDY AREA AND MATERIAL}

Neva Bay is a freshwater part of the Gulf of Finland where salinity does not exceed 0.2 PSU (Fig. 1). The area of Neva Bay is $329 \mathrm{~km}^{2}$, its length is $21 \mathrm{~km}$, and the greatest width is $15 \mathrm{~km}$. The predominant depths are $3-5 \mathrm{~m}$ but in the area of bottom depressions they reach 7-8 $\mathrm{m}$ (Shiklomanov et al., 1989). One of the major features of the state of Neva Bay is a high rate of water exchange. The water in Neva Bay is renewed every 2.5-5.5 days (Alimov et al., 1996).

The eastern Gulf of Finland can be divided conventionally into a shallow zone (inner estuary) with a depth of 13-25 $\mathrm{m}$ and salinity 1-2 PSU, and a deep-water zone (outer estuary) with a depth of 25-50 m and salinity 2-7 PSU (Fig. 1).

The dissolved oxygen level in Neva Bay is always higher than $5 \mathrm{mgO}_{2} \mathrm{~L}^{-1}$, while in the outer estuary anoxic conditions sometimes occur near the bottom (Shishkin et al., 1989; Fedorova, 1997).

The present study was based upon samples of zoobenthos, collected by the staff of the Laboratory of Freshwater and Experimental Hydrobiology of the Zoological Institute of the Russian Academy of Sciences in late September through early October in 1994 and 1995, in August 1996, 1997, and 1998, and in June 2001. The number of stations studied in different years in Neva Bay and the eastern part of the Gulf of Finland is given in Table 1, sampling stations are shown in Figs. 1-4. 


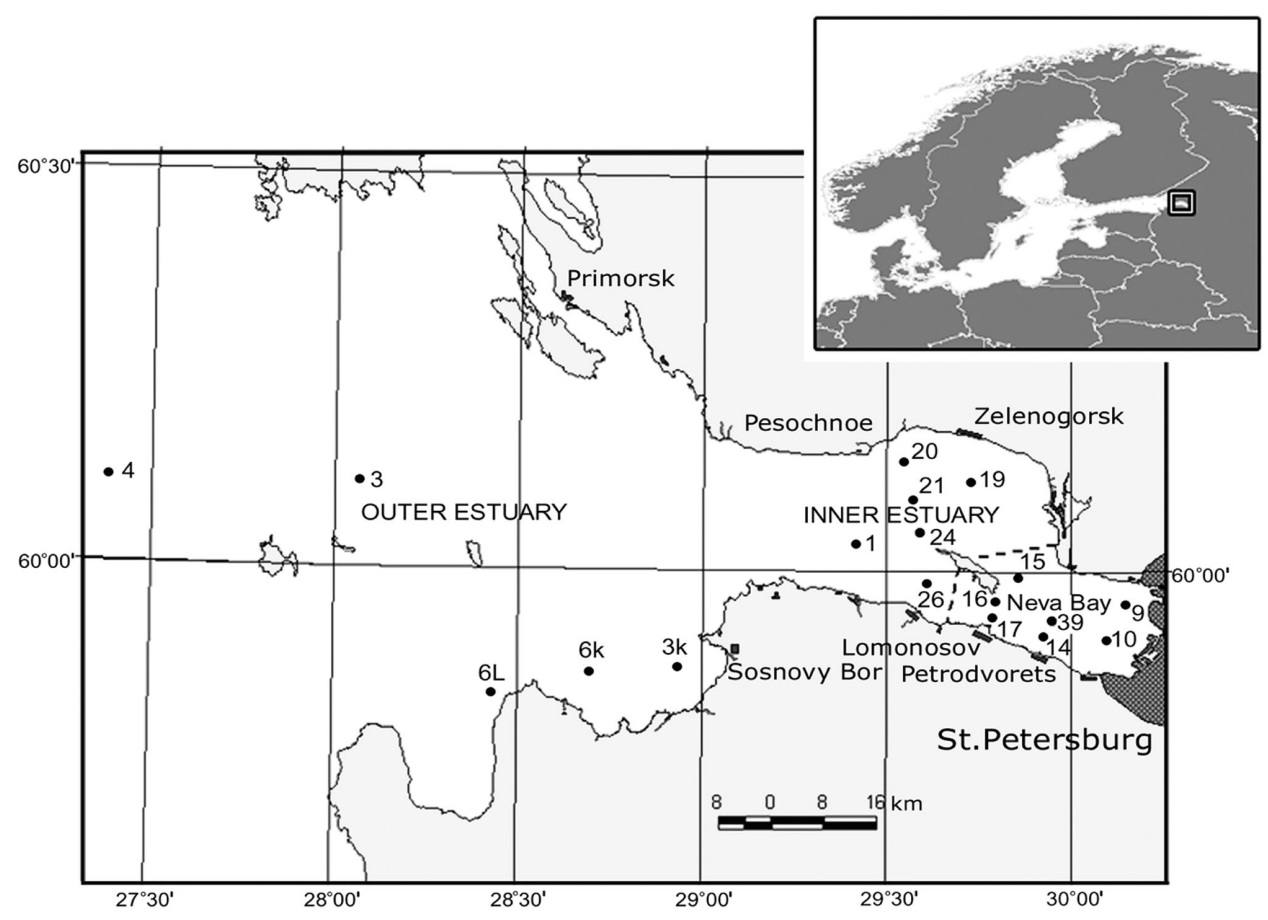

Fig. 1. Sampling stations in Neva Bay and the eastern Gulf of Finland in 1994-95.

Table 1. Number of stations studied in Neva Bay and the eastern Gulf of Finland in different years

\begin{tabular}{l|c|c|c|c|c|c}
\hline & 1994 & 1995 & 1996 & 1997 & 1998 & 2001 \\
\hline Neva Bay & 5 & 5 & 31 & 36 & 34 & 23 \\
Gulf of Finland & 9 & 9 & 14 & 24 & 0 & 13
\end{tabular}

\section{METHODS}

Zoobenthos was sampled using a modified Petersen bottom grab with a sampling area of $0.025 \mathrm{~m}^{2}$ and sieved in the field through a $0.25 \mathrm{~mm}$ mesh. Two to three parallel samples were taken at each station. Zoobenthos samples were preserved with $4 \%$ formalin and treated in laboratory using standard methods (Telesh et al., 1999). 
Collection of zoobenthos samples and their examination by family were conducted by T. D. Slepukhina and M. A. Barbashova from the Institute of Lake Research and by S. M. Golubkov, V. E. Panov, and A. A. Maximov from the Zoological Institute.

Identification of animals to a species was performed by N. P. Finogenova (oligochaetes and leeches), Ya. I. Starobogatov (molluscs), E. V. Balushkina (chironomids), and T. D. Slepukhina (amphipods).

We had to move from a controversial assessment of water quality based upon different indices to an integrated one including a set of indices providing the most complete characterization of an animal community as a whole and reflecting specific features of anthropogenic impact on an ecosystem. The scale of the Integrated Index (Balushkina, 1997) incorporates the data of four indices: (1) Woodiwiss Index BI (Woodiwiss, 1964), (2) Index Kch (Balushkina, 1987), (3) Index No/Nc (Goodnight \& Whitley, 1961), and (4) Saprotoxobic index St (Yakovlev, 1988).

With an increase of pollution the values of the indices ST, No/ $\mathrm{Nc}$, and Kch increased, whereas the values of BI declined. Therefore we expressed the value of BI by an inverse value (1/BI). The values of the index increase with an increase of pollution from 0.1 to 1 . So the index $1 / \mathrm{BI}$ acquires the same directionality as the other three indices. Different dimensionality of the indices hampers comparison of their absolute values. The values of No/Nc are expressed as percentages; therefore, the parameters St, Kch, and 1/BI are expressed as percentages of their maximum values.

In fresh waters the scale of the new Integrated Index (IP) sums up the data of these four indices. In brackish waters chironomids were frequently absent and it was not possible to calculate the Kch index based on structural characteristics of chironomids. For the assessment of the impact of biotic and abiotic factors in fresh and brackish waters it is more convenient to use average values of these four or three indices - the Integrated Index $\left(\mathrm{IP}^{\prime}\right)$ - rather than the total value.

The new Integrated Index $\left(\mathrm{IP}^{\prime}\right)$ may be used for determining water quality of fresh and brackish ecosystems with mixed organic and toxic pollution. The character of the $\mathrm{IP}^{\prime}$ scale allows quantitative characterization of continuous anthropogenic changes of water quality. The method for the assessment of water quality, information on each index, and methods of their calculation and application were treated in greater detail earlier (Balushkina, 1997).

We accepted the gradations of water quality and the state of an ecosystem according to the recommendations of Drachev (1964) and the Ministry of Environmental Protection of Russia (Criteria of Assessment, 1992) (Table 2). For a more detailed study of the changes in waters of class 4 we distinguished an additional transitional class "polluted-dirty" for the cases IP values exceed 265, which corresponds to a "critical" state of an ecosystem (Balushkina \& Finogenova, 1999; Balushkina, 2002) (Table 2). 
Table 2. Classes of the state of water and quality of the ecosystem of Neva Bay and the eastern Gulf of Finland by zoobenthos indices St, No/Nc, Kch, 1/BI, and the Integrated Indices IP and IP'

\begin{tabular}{c|c|c|c|c|c|c|c|c}
\hline St & No/Nc & Kch & 1/BI & IP & IP' & $\begin{array}{c}\text { Water } \\
\text { class } \\
\text { number }\end{array}$ & Quality of water & $\begin{array}{c}\text { State of the } \\
\text { ecosystem }\end{array}$ \\
\hline 25 & 0 & 1.22 & 10 & 36.2 & 9.05 & 1 & Very clean & \\
37.5 & 50 & 9.4 & 20 & 116.9 & 29.22 & 2 & Clean & Relatively satisfactory \\
62.5 & 60 & 56.5 & 33 & 212 & 53 & & $\begin{array}{c}\text { Moderately } \\
\text { polluted }\end{array}$ & Tense \\
& & & & 265 & 66.25 & 4 & Polluted & Critical \\
87.5 & 80 & 78.26 & 50 & 295.8 & 73.95 & $5-5$ & Polluted-Dirty & Crisis \\
100 & 100 & 100 & 100 & 400 & 100 & & Dirty & Catastrophic
\end{tabular}

\section{RESULTS \\ Neva Bay}

Approximately 90 species of benthic animals inhabit currently Neva Bay. Oligochaetes, bivalve molluscs, and chironomid larvae predominate. These groups of animals form nearly $100 \%$ of the zoobenthos biomass and occur in certain proportions throughout the entire Neva Bay. Animals of other taxa are rare.

In 1994 through 2001 the role of oligochaetes increased gradually, whereas the role of other taxa of benthic invertebrates declined. In most cases oligochaetes comprised $70-100 \%$ of the total abundance of benthic organisms. Oligochaetes also contribute greatly to the benthos biomass. Nearly everywhere (except for stations where unionids or large gastropods were predominant) oligochaetes biomass exceeded $40-70 \%$. On polluted grounds in the port and in the sea channel and also in the impact zone of effluents from sewage treatment oligochaetes biomass reached $80-90 \%$ of the entire biomass of benthic animals.

In 1994 through 2001 Limnodrilus hoffmeisteri Clap. and Potamothrix hammoniensis (Mich.), highly productive species typical of water bodies affected by anthropogenic impact, were predominant. Small bivalve molluscs, with most common pisidiids Henslowiana suecica (Clessin), Cingulipisidium fedderseni (Weserlund), Neopisidium tenuilineatum (Stelfox), Pisidium amnicum (Mull.) and the spheriids Amesoda draparnaldi (Clessin), attained maximum development in the central part of Neva Bay. In the western and central parts of the bay aggregations of the unionids Colletopterum piscinale (Nilsson) and Tumidiana tumida (Philipsson) were noted.

Larvae of the chironomids Cryptochironomus defectus Kieff., Chironomus f.l. plumosus L., and Procladius ferrugineus K. are spread throughout Neva Bay. On clean and muddy sands in the region of maximum water flow velocity 
populations of Psectrocladius simulans Joh., Cladotanytarsus mancus Walk, and Microtendipes pedellus (De Geer) are also numerous.

The results of the assessment of water quality and the state of Neva Bay in 1997 and 2001 are presented in Figs. 2 and 3. In 1994-2001 "moderately polluted" waters were noted in Neva Bay in the mouth of the Neva River, i.e. in the area of the maximum water flow velocity, and in the area of the northern gate of the storm-surge barrier (Fig. 2). In 1998 the area of "moderately polluted" waters in Neva Bay decreased, and adjoining areas were assessed as "polluted-dirty", the state as "crisis". In 2001 the state of this region slightly improved (Fig. 3). The assessment of the state in the region of station 7 (Fig. 3) situated close to the northern gate of the storm-surge barrier as "moderately polluted" was in full agreement in 1998 and 2001 (IP values 189.7 and 209.2, respectively). Other areas of Neva Bay were assessed by IP as "polluted" and "polluted-dirty", the state as "critical" and "crisis" (Fig. 3).

Quantitative development of benthic animals in Neva Bay in 1994-2001 was to the largest extent determined by pollution: zoobenthos numbers and biomass increased with growing pollution. The mean numbers and biomass of zoobenthos in the area of "moderately polluted" waters were 12250 ind. $\mathrm{m}^{-2}$ and $41.7 \mathrm{~g} \mathrm{WW} \mathrm{m}$, respectively; in the transitional class of "polluted-dirty" waters they reached 34600 ind. $\mathrm{m}^{-2}$ and $56.9 \mathrm{~g} \mathrm{WW} \mathrm{m}^{-2}$; in the class of "dirty" waters the numbers of benthic animals increased up to 39500 ind. $\mathrm{m}^{-2}$ and biomass up to $69.3 \mathrm{~g} \mathrm{WW} \mathrm{m}^{-2}$.

More detailed information on the changes occurring in bottom communities under the influence of water quality improvement can be obtained by the example of the station situated in the open part of the bay in the Petrodvorets section (Fig. 2, station N20).

During the years of observations 57 taxa of benthic animals were found at station N20 (designated as station N20 in Fig. 2 and as station 14 in Figs. 1 and 3). The tendency towards purification at this station is relatively stable and can be traced since 1994 through 1997 (Table 3). Since 1994 the abundance of zoobenthic animals at this station declined from 16260 to 2010 ind. $\mathrm{m}^{-2}$. The number of species increased from 12 to 27, species diversity (Shannon index) increased from 2.15 to 3.8 (Table 3 ).

The predominance of oligochaetes declined on the whole considerably and the values of the $\mathrm{No} / \mathrm{Nc}$ index decreased respectively (from 90.5 to 58.7). A notable increase in the diversity of the community as a whole reflected upon the decline of the index 1/BI (reverse value of the Woodiwiss index). The values of IP declined in those years regularly (from 263.3 in 1994 to 197.4 in 1997) and the water quality by the IP index improved by one class (Table 3 ).

The major characteristic of this part of Neva Bay (designated as station N20 in Fig. 2 and station 14 in Fig. 3) includes a notable increase of the biomass of large unionid molluscs observed during the years of study (Table 3). Possibly some improvement of the water quality at station N20 (14) favoured a considerable increase in the biomass of bivalves, which in turn, owing to their filtration activity, provided for a higher degree of "self-purification", which was particularly high in 1994-97. However, at station N20 (14) that phenomenon was local because its 


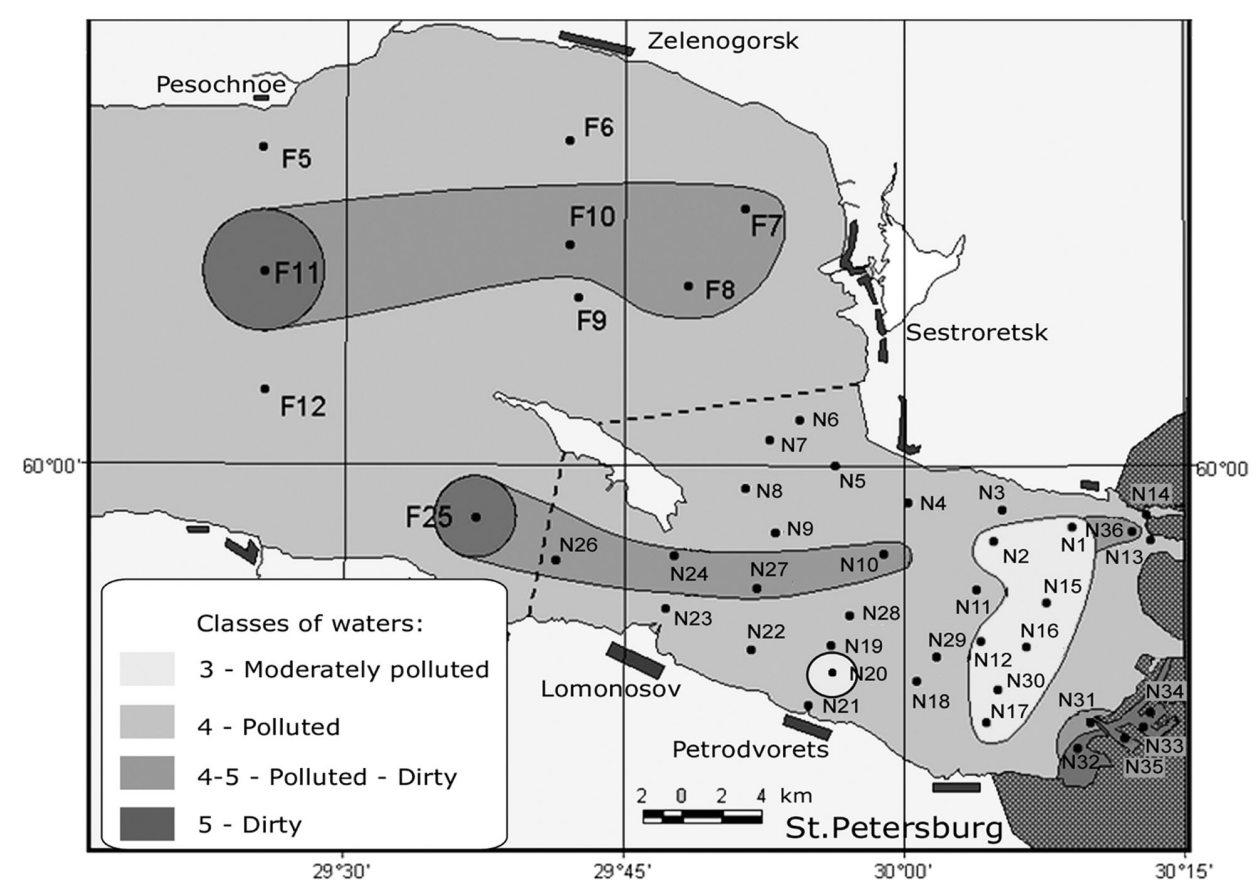

Fig. 2. The quality of waters and the state of ecosystems of Neva Bay and the eastern Gulf of Finland by Integrated Index in 1997.

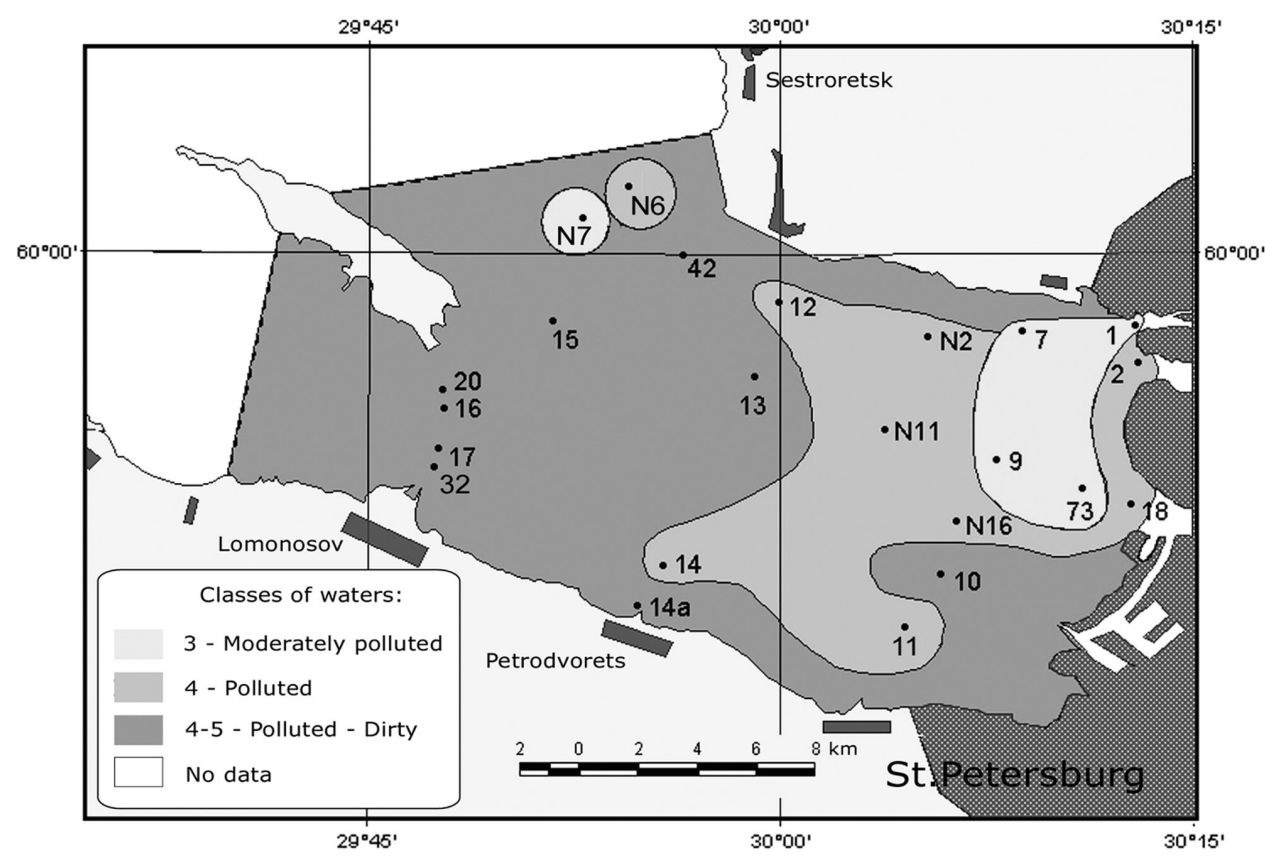

Fig. 3. The quality of waters and the state of ecosystems of Neva Bay by Integrated Index in 2001. 
Table 3. Changes of the structural characteristics in zoobenthic communities and assessment of the water quality and the state of the ecosystem of Neva Bay at station N20 (14) in 1994-2001

\begin{tabular}{|c|c|c|c|c|c|c|}
\hline & 1994 & 1995 & 1996 & 1997 & 1998 & 2001 \\
\hline Total abundance, ind. $\mathrm{m}^{-2}$ & 16260 & 9560 & 7360 & 2010 & 6560 & 6400 \\
\hline Total biomass, $\mathrm{g} \mathrm{m}^{-2}$ & 21.34 & 19.84 & 16.5 & 162 & 177 & 629 \\
\hline $\begin{array}{l}\text { Biomass without unionids, } \\
\mathrm{g} \mathrm{m}^{-2}\end{array}$ & 21.34 & 19.84 & 2.38 & 1.85 & 7.11 & 4.4 \\
\hline Number of species & 12 & 13 & 14 & 27 & 17 & 16 \\
\hline Shannon index, bit ind. ${ }^{-1}$ & 2.2 & 2.5 & 2.4 & 3.8 & 2.3 & 3.14 \\
\hline Index $\mathrm{No} / \mathrm{Nc}, \%$ & 90.5 & 68.7 & 70.6 & 58.7 & 95.6 & 97.5 \\
\hline Index St, \% & 69.7 & 75 & 82.5 & 57 & 57.5 & 46.8 \\
\hline Index Kch, \% & 69.7 & 69.8 & 39 & 67.4 & 63.8 & 56.5 \\
\hline Index BI, \% & 33.3 & 33.3 & 33.3 & 14.3 & 33.3 & 50 \\
\hline Integrated Index IP, \% & 263.3 & 246.7 & 225.4 & 197.4 & 250.2 & 250.8 \\
\hline Class of water & 4 & 4 & 4 & 3 & 4 & 4 \\
\hline Quality of water & Polluted & Polluted & Polluted & $\begin{array}{l}\text { Moderately } \\
\text { polluted }\end{array}$ & Polluted & Polluted \\
\hline State of the ecosystem & Critical & Critical & Critical & Tense & Critical & Critical \\
\hline
\end{tabular}

surrounding area was assessed as "polluted" in 1994-97 and as "polluted-dirty" in 1998 and 2001 (Figs. 2 and 3).

The impact of pollution at station N20 (14) in 1998-2001 increased and the water quality in that part of Neva Bay worsened again by one class, in spite of the notable increase in the unionid biomass (Table 3 ).

The same type of benthic animal communities is characteristic also of other parts of Neva Bay in the areas of stations N2, N4, N11, N13, N21, and N23 (Fig. 2).

\section{The eastern Gulf of Finland}

In 1994-2001 eurybiont freshwater species - oligochaetes, chironomid larvae, and molluscs of the Pisidiidae family - were noted in the shallow area of the eastern Gulf of Finland (inner estuary). In the biomass these were appreciably predominant over other groups of aquatic organisms. At present, the relict crustaceans Mysis relicta Loven, Saduria entomon (L.), Pallasea quadrispinosa (Sars), and Monoporeia affinis Lindstr. are represented by only a few specimens in that zone.

In 1994-95 Macoma balthica L., Marionina argentea (Mich.), Amphichaeta sannio Kallstenius, and Paranais litoralis (O. F. Muller) were predominant at depths 26-50 m (outer estuary). In 2001 in the deep water zone the brackish-water oligochaetes Nais elinguis Mull. and polychaetes Marenzelleria viridis (Verrill) were predominant. In the 1990s only single specimens of such species as Saduria entomon occurred and the number of Monoporeia affinis diminished considerably.

A particularly detailed study of the state of the shallow zone of the eastern Gulf of Finland was conducted in 1997. Our data suggest heavy pollution of the shallow zone. At stations F11 and F25 waters were assessed as "dirty", and the state of the ecosystem as "catastrophic" (Fig. 2). 


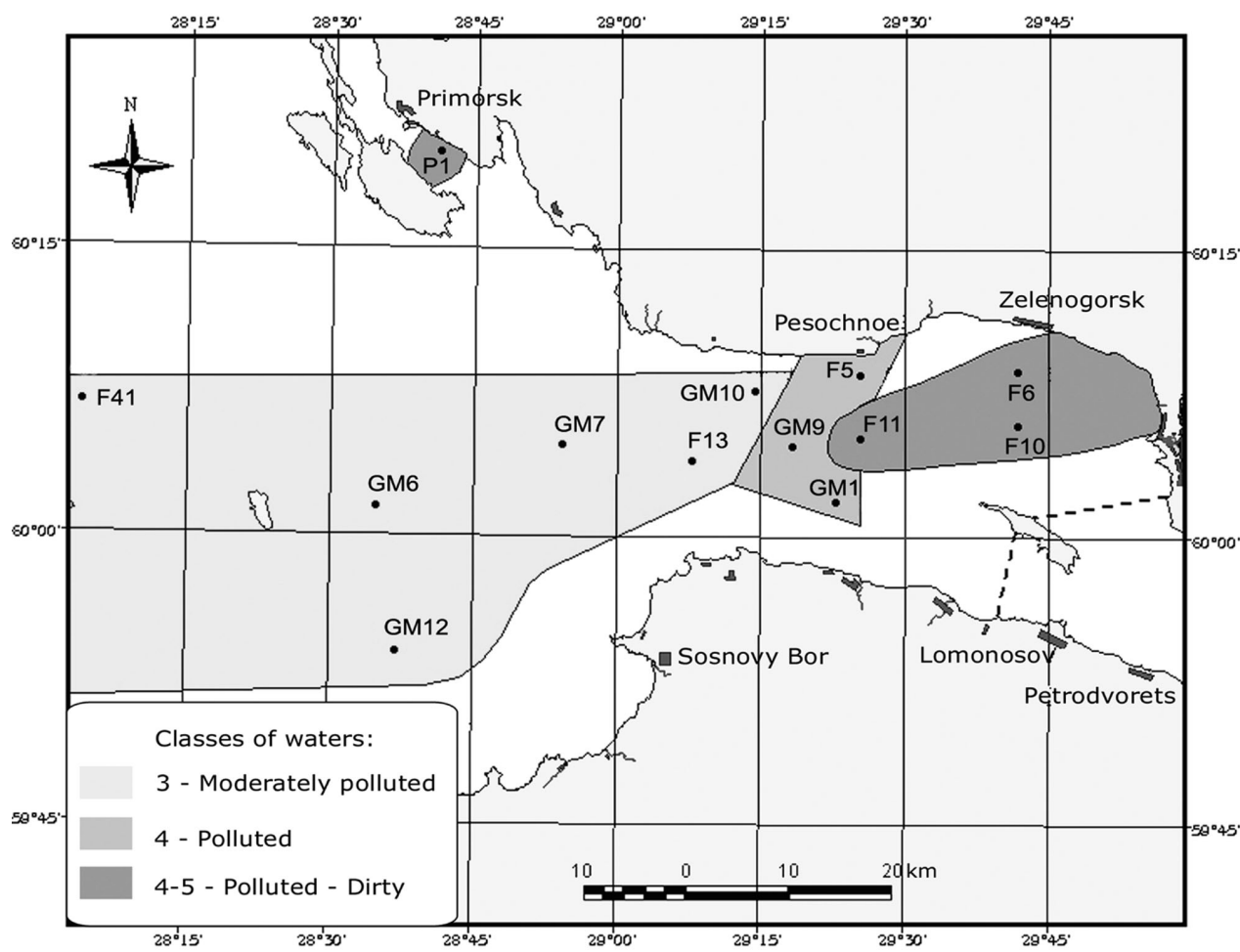

Fig. 4. The quality of waters and the state of ecosystems of the eastern Gulf of Finland by Integrated Index in 2001.

The assessment of the state of the eastern Gulf of Finland in 2001 showed that with an increase of depth and salinity in the western direction the degree of pollution declined (Fig. 4).

The abundance and biomass of zoobenthos were determined by a combination of the values of pollution and salinity. In the shallow-water zone of the eastern Gulf of Finland at salinities of 2.87-3.23 PSU these values were relatively high (12 700-20 800 ind. $\mathrm{m}^{-2}$ and 14.4-31.3 $\mathrm{g} \mathrm{WW} \mathrm{m}^{-2}$ ) in the region of "polluted-dirty" waters (Fig. 4). With an increase of salinity to 3.8 PSU and decline of the degree of pollution to "moderately polluted" in the western direction the numbers and biomass of zoobenthos declined to 2800 ind. $\mathrm{m}^{-2}$ and $0.9 \mathrm{~g} \mathrm{WW} \mathrm{m}^{-2}$ and increased at salinity of $6.98 \mathrm{PSU}$ to 5800 ind. $\mathrm{m}^{-2}$ and $34.5 \mathrm{~g} \mathrm{WW} \mathrm{m}{ }^{-2}$, respectively.

\section{DISCUSSION}

Historical data show that at the beginning of the 20th century Neva Bay and the eastern Gulf of Finland could be classified as oligotrophic, and the state of the ecosystems was determined by natural processes (Finogenova et al., 1987; Alimov et al., 1996; Telesh et al., 1999; Golubkov et al., 2003). In the benthic communities of Neva Bay the glacial relict crustaceans Pallasea quadrispinosa 
Sars, Pontoporeia affinis Lindstrom, and Mysis relicta Loven - inhabitants of clean waters - were dominant then (Skorikov, 1910).

In the 1920s (Derjugin, 1925) the species composition of benthos altered. The relict crustaceans Pontoporeia affinis and Mysis relicta were not discovered, Pallasea quadrispinosa became scanty.

The recent appearance of the benthic fauna of Neva Bay was formed in the 1930s when the importance of the relict crustacean Pallasea quadrispinosa declined abruptly and the role of oligochaetes increased. In the western part of Neva Bay oligochaetes and bivalves became predominant (Derjugin, 1925; Finogenova at al., 1987, 1999).

The changes in the benthic communities of Neva Bay in the last twenty years may be the result of the alteration of the suspended organic matter due to the construction of the Central and the Northern Wastewater Treatment Plants in Neva Bay. In the 1980s the biomass of benthos attained extreme values of more than $1 \mathrm{~kg} \mathrm{WW} \mathrm{m}^{-2}$ in the eastern part of Neva Bay, mostly owing to oligochaetes, pisidiids and spheriids (Finogenova et al., 1987, 1999). In the 1990s the technology of sewage treatment improved considerably and the degree of pollution declined, and in 1994-2001 the biomass of benthos dropped to 41.7-56.9 $\mathrm{g} \mathrm{WW} \mathrm{m}^{-2}$ in the eastern part of Neva Bay.

In the eastern Gulf of Finland the most notable changes during the 20th century took place in the benthic animal communities of the shallow-water zone. At the beginning of the 20th century the relict crustaceans Mysis relicta, Saduria entomon, Pallasea quadrispinosa, and Monoporeia affinis were predominant in that zone (Skorikov, 1910). At present relict crustaceans are only represented by solitary specimens there. In the 1990s predominance of oligochaetes up to $90 \%$ and more was recorded in those areas. It is beyond any doubt that by structural characteristics such communities are far from being "normal". The replacement of molluscs by oligochaetes, animals with a lower metabolic rate, leads to a decline in the efficiency of self-purification processes. In 1994-2001 the biomass of zoobenthos was the highest in the shallow-water zone of the eastern Gulf of Finland (14.4-31.3 $\mathrm{g} \mathrm{WW} \mathrm{m}^{-2}$ ).

An increase in the abundance and biomass of marine benthos accompanying eutrophication has been demonstrated in different Baltic areas (Pearson \& Rosenberg, 1978; Persson, 1987). Cederwall \& Elmgren (1980) showed that benthic biomass increased significantly (4-7 times) in the central Baltic over the period from 1921 to 1976-77. This increase was attributed to growing eutrophication.

Since the beginning of the 20th century zoobenthos in the deep-water zone of the eastern Gulf of Finland has changed greatly. The numbers and biomass of the relict crustaceans Monoporeia affinis occurring in "clean" waters decreased. Similar changes took place in the Finnish coastal zone of the Gulf of Finland (Kauppila \& Bäck, 2001).

The changes in the benthic communities of the eastern Gulf of Finland in the last twenty years may be the result of the alteration of the hydrological regime caused by the storm-surge barrier. Moreover, ineffective local water management in St. Petersburg has stimulated the development of a natural "biological plug" in the salt barrier zone in the shallow water part of the eastern Gulf of Finland and 
altered the ecosystem's functioning (Golubkov et al., 2003). Anthropogenic input of nutrients further stimulates the development of the natural "biological plug" and leads to a very high primary production of phytoplankton. In that part of the eastern Gulf of Finland the numbers and biomass of zoobenthos were the highest in the 1990s and the state of the ecosystem was assessed by $\mathrm{IP}^{\prime}$ in 2001 as "crisis" (Fig. 4).

In 1994-95 a study was conducted on the influence of 42 hydrophysical and hydrochemical parameters of the Neva estuary, measured simultaneously, on zoobenthos structural characteristics and on the values of calculated indices (Balushkina, 2002). Analysis of Pearson correlations shows that the number of species in Neva Bay and the eastern Gulf of Finland (salinity 0.1-2 PSU) is determined also by high concentrations of toxicants, surfactants, heavy metals, and oil products in water and bottom sediments. Growing DDT concentrations resulted in the death of animals and a decline of total abundance (Balushkina, 2002).

Increasing pollution in the studied system as a whole induces a growth in the numbers and biomass of benthic animals and a decline of their species diversity. The increasing proportion of oligochaetes in zoobenthos, which implies growing organic pollution, should be regarded as a general unfavourable tendency in the structure of benthic communities in Neva Bay and in the shallow-water zone of the eastern Gulf of Finland. It should be emphasized that in 1994-95, as compared to the 1980s, the proportion of anomalous individuals with morphological deviations in the common oligochaete species Spirosperma ferox increased (Finogenova et al., 1999). Abnormalities were also noted in chironomid larvae. Apparently the morphological abnormalities were caused by increasing toxicity of the habitat in the 1990s (Finogenova et al., 1999).

By characteristics of benthic communities the state of a large part of Neva Bay and the eastern Gulf of Finland may be assessed as "crisis" (4-5 class of waters) of the ecosystem. According to the classification of the Ministry of Environmental Protection (Criteria of Assessment, 1992) the ecologically unfavourable situation "crisis" is characterized by stable negative changes in an ecosystem that pose a threat to the population.

The evaluation using the standards of the quality of surface waters (by chemical characteristics) indicated that in 2001 a large portion of the waters of Neva Bay belonged to class 4 (Basova et al., 2002). According to this classification the water of class 4 is unfit for water supply, fish farming, and recreation even after treatment. In industrial production it can be used only after treatment.

\section{ACKNOWLEDGEMENTS}

We would like to express our deep gratitude to Academician A. F. Alimov and Dr. S. M. Golubkov for their important assistance and also to the team that participated in the study conducted in the estuary of the Neva River, in particular to A. A. Maximov and V. E. Panov. We are grateful to the Ministry of Industry, Science and Technology (grant No. S.S.-1634.2003.4) and the Russian Foundation for Basic Research (grant No. 02-04-48646) and INTAS N 99674 for partly supporting this study. 


\section{REFERENCES}

Alimov, A. F. \& Golubkov, S. M. 1987. Functional importance of zoobenthos in the ecosystem of the Neva Bay. In The Neva Bay. Hydrobiological Studies (Winberg, G. G. \& Gutelmacher, B. L., eds.), pp. 170-174. Nauka, Leningrad (in Russian).

Alimov, A. F., Golubkov, S. M. \& Panov, V. E. 1996. Regularities of functioning and strategy for management of the ecosystems in the estuary of the Neva River. In Ecological State of Water Bodies and Water Flows of the Neva River Drainage Basin (Alimov, A. F. \& Frolov, A. K., eds.), pp. 187-203. Scientific Center RAS (in Russian).

Balushkina, E. V. 1987. Functional Significance of Chironomid Larvae in Continental Reservoirs. Nauka, Leningrad (in Russian).

Balushkina, E. V. 1997. New Integrated Index for water quality evaluation based on structural characteristics of zoobenthos. In Proceedings of the Final Seminar of the Gulf of Finland Year 1996, pp. 177-202. Oy Edita Ab, Helsinki.

Balushkina, E. V. 2002. The importance of structural characteristics of benthic animals in the evaluation of river and estuary ecosystems. Proc. ZIN RAS, 296, 13-20.

Balushkina, E. V. \& Finogenova, N. P. 1999. Zoobenthos structural characteristics as a basis for the assessment of the ecosystems state in the Neva Bay and the eastern part of the Gulf of Finland. In Structural-functional Organisation of Freshwater Ecosystems of Different Types (Alimov, A. F. \& Ivanova, M. B., eds.). Proc. ZIN RAS, 279, 269-292 (in Russian).

Basova, S. I., Kobeleva, N. I., Leonova, M. V. \& Frumin, G. T. 2002. Characterization of the state of the Neva Bay by hydrochemical indices in 2001. In Environmental Protection, Nature Management and Providing Ecological Safety in St. Petersburg in 2001 (Golubev, D. A. \& Sorokin, N. D., eds.), pp. 175-182. Administration of St. Petersburg (in Russian).

Cederwall, H. \& Elmgren, R. 1980. Biomass increase of benthic macrofauna demonstrates eutrophication of the Baltic Sea. Ophelia, Suppl. 1, 287-304.

Criteria of Assessment of Ecological Situation of Territories for Revealing Zones of Emergency Ecological Situation and Ecological Disaster. 1992. The Ministry of Environmental Protection, Moscow (in Russian).

Derjugin, K. M. 1925. Hydrological and hydrobiological studies of the Neva Bay. In Hydrology and Benthos of the Eastern Part of the Gulf of Finland. Studies of the Neva River and Its Basin, pp. 3-48. Leningrad (in Russian).

Drachev, S. M. 1964. Control of Pollution of Rivers, Lakes and Reservoirs by Industrial and Domestic Effluents. Nauka, Moscow, Leningrad (in Russian).

Fedorova, N. K. 1997. Geochemistry of bottom waters in the eastern Gulf of Finland. Abstract of the Ph.D. Thesis. St. Petersburg (in Russian).

Finogenova, N. P., Golubkov, S. M., Panov, V. E., Balushkina, E. V, Pankratova, V. Ya., Lobasheva, T. M. \& Pavlov, A. M. 1987. Macrobenthos. Neva Bay. In Hydrobiological Studies (Winberg, G. G., ed.), pp. 111-120. Nauka, Leningrad (in Russian).

Finogenova, N. P., Slepukhina, T. D., Golubkov, S. M., Balushkina, E. V., Starobogatov, Ya. I. \& Barbashova, M. A. 1999. Composition and quantitative indices of benthic invertebrates. In Gulf of Finland under Conditions of Anthropogenic Impact (Rumyantsev, V. A. \& Drabkova, V. G., eds.), pp. 189-211. Institute of Limnology RAS, St. Petersburg (in Russian).

Golubkov, S. M., Alimov, A. F., Anokhina, L. E., Maximov, A. A., Nikulina, V. N., Pavel'eva, E. B. \& Panov, V. E. 2003. Functional response of midsummer planktonic and benthic communities in the Neva Estuary (eastern Gulf of Finland) to anthropogenic stress. Oceanologia, 45(1), 53-66.

Goodnight, C. J. \& Whitley, L. S. 1961. Oligochaetes as indicators of pollution. Proc. 15-th Ind. Waste Conv., 106, 139-142.

Izrael, Yu. A. \& Abakumov, V. A. 1991. On the ecological state of surface waters of the USSR and criteria of ecological standards. In Ecological Modifications and Criteria of Ecological Standards, pp. 7-17. Gidrometeoizdat, Leningrad (in Russian). 
Johnson, R. K., Wiederholm, T. \& Rosenberg, D. M. 1992. Freshwater biomonitoring using individual organisms, populations, and species assemblages of benthic macroinvertebrates. In Freshwater Biomonitoring and Benthic Macroinvertebrates (Rosenberg, D. M. \& Resh, V. H., eds.), pp. 40-159. New-York, London.

Kauppila, P. \& Bäck, S. (eds.). 2001. The State of Finnish Coastal Waters in the 1990s. The Finnish Environment, Helsinki.

Leppäkoski, E. 1975 Macrobenthic fauna as indicator of oceanization in the Southern Baltic. Merentutkimuslait. Julk. Havsforskningsinst. Skr., 239, 280-288.

Pearson, T. H. \& Rosenberg, R. 1978. Macrobenthic succession in relation to organic enrichment and pollution of the marine environment. Oceanogr. Mar. Biol. Ann. Rev., 16, 229-311.

Persson, L. E. 1987. Baltic eutrophication: a contribution to the discussion. Ophelia, 27(1), 31-42.

Skorikov, A. S. 1910. Zoological Studies of Ladoga Water as Drinking Water. St. Petersburg (in Russian).

Shiklomanov, I. A., Praeobrazhensky, L. Yu., Skakalsky, B. G. \& Shishkin, B. A. 1989. Hydrological and ecological studies in water system: Lake Ladoga-Neva River-Neva Bay. Izv. $V N I G, 213,14-29$ (in Russian).

Shishkin, B. A., Nikulina, V. N., Maksimov, A. A. \& Silina, N. I. 1989. Main Characteristics of the Biota of the Gulf of Finland and Its Role in Formation of Water Quality. Gidrometeoizdat, Leningrad (in Russian).

Telesh, I. V., Alimov, A. F., Golubkov, S. M., Nikulina, V. N. \& Panov, V. E. 1999. Response of aquatic communities to anthropogenic stress: a comparative study of Neva Bay and the eastern Gulf of Finland. Hydrobiologia, 393, 95-105.

Woodiwiss, F. S. 1964. The biological system of stream classification used by the Trent Board. Chem. a. Ind., 11, 443-447.

Yakovlev, V. A. 1988. The Assessment of Freshwaters Quality of Kola North by Hydrobiological Parameters and the Data of Toxicity Tests (Kryuchkov, V. V., ed.). Kola Branch AS USSR, Apatity (in Russian).

\section{Neeva lahe ja Soome lahe idaosa vee kvaliteedi ja ökosüsteemi seisundi hinnang põhjaloomastiku koosluste struktuuri muutuste põhjal aastatel 1994-2001}

\section{Evgeniya V. Balushkina ja Nonna P. Finogenova}

Neeva lahe ja Soome lahe idaosa põhjaloomastiku koosluste määramisel olid aluseks erinevad näitajad, nagu liigiline koosseis, liikide arv, arvukus, biomass ja nende põhjal arvutatud indeksid (Shannoni mitmekesisuse indeks). Vee kvaliteeti hinnati integreeritud indeksi abil, mida oli kohandatud uuritavatele ökosüsteemidele.

Ajavahemikus 1994-2001 tõusis kirjeldatud ökosüsteemides oligoheetide osatähtsus järk-järgult, teiste taksonite oma langes. 2001. aastal hinnati suure osa vaadeldava merepiirkonna vee kvaliteeti kui tugevasti saastatut. Ökosüsteem oli kriisiseisundis. Soome lahe idaosa seisundi hinnang näitas, et sügavuse ja merevee soolsuse suurenedes lääne suunas vähenes ka saastatuse tase. 